удК 338.3.01:658

\title{
МЕТОДИЧНИЙ ПІДХІД ДО ІНТЕГРАЛЬНОЇ ОЦІНКИ КОНКУРЕНТНОГО ПОТЕНЦІАЛУ ВИРОБНИЧОГО ПІДПРИЕМСТВА
}

\section{METHODICAL APPROACH TO THE INTEGRATED ASSESSMENT OF THE COMPETITIVE POTENTIAL OF THE PRODUCTION ENTERPRISE}

\author{
Базилюк Володимир Богданович \\ доктор економічних наук, профресор, \\ Українська академія друкарства \\ ORCID: https://orcid.org/0000-0002-8627-1105 \\ Базилюк Ксенія Федорівна \\ кандидат технічних наук, доцент, \\ Національний університет «Львівська політехніка» \\ ORCID: https://orcid.org/0000-0002-6189-8446 \\ Bazyliuk Volodymyr
Ukrainian Academy of Printing \\ Bazyliuk Kseniya \\ Lviv Polytechnic National University
}

\begin{abstract}
Розглянуто переваги та недоліки основних методів оцінки конкурентоспроможності підприємств. Запропоновано авторський підхід до оцінки конкурентного потенціалу виробничого підприємства, що полягає в інтегральній оцінці по шести елементах (виробничому, трудовому, фрінансовому, інноваційному, маркетинговому і управлінському), що чинять безпосередній вплив на конкурентоспроможність потенціалу. Сфрормовано методику розрахунку конкурентоспроможності потенціалу господарюючого суб'єкта на основі методу ранжирування фракторів за допомогою експертних оцінок, яка базується на системі показників оцінки та враховує вплив кожного із складових елементів. Розглянуто основні переваги та обмеження застосування на практиці представленої методики.
\end{abstract}

Ключові слова: конкуренція, конкурентний потенціал, оцінка конкурентоспроможності, інтегральний метод, виробниче підприємство.

Рассмотрены преимущества и недостатки основных методов оценки конкурентоспособности предприятия. Предложено авторский подход к оценке конкурентного потенциала производственного предприятия, что заключается в интегральной оценке по шести элементах (производственном, трудовом, фринансовом, инновационном, маркетинговом и управленческом), что оказывают непосредственное влияние на конкурентоспособность потенциала. Сорормировано методику расчета конкурентоспособности потенциала хозяйствующего субъекта на основе метода ранжирования фракторов с помощью экспертных оценок, основанною на системе показателей оценки, что учитывает влияние каждого с составляющих элементов. Рассмотрены основные преимущества и ограничения применения на практике представленной методики.

Ключевые слова: конкуренция, конкурентный потенциал, оценка конкурентоспособности, интегральный метод, производственное предприятие.

The global changes inherent in the economic processes of recent years necessitate the formation of modern approaches to increasing the competitiveness of the potential of industrial enterprises. Its assessment becomes relevant taking into account the impact of key performance indicators in order to ensure further sustainable development of manufacturing enterprises in a constantly changing market environment. The objectives of the article are the scientific substantiation of the theoretical and methodological basis and methodological approach to the integrated assessment of the competitive potential of the production enterprise, as well as the development of practical recommendations based on the findings in this area. The advantages and disadvantages of the main methods of assessing the 
competitiveness of enterprises are considered. It is substantiated that in the formation of methods for assessing the competitiveness of the potential of industrial enterprises it is advisable to use methods that can have wide practical application, namely: expert methods, rating comparative analysis, simulation, factor analysis, economic and mathematical modeling, and integrated method. The author's approach to the assessment of the competitive potential of a manufacturing enterprise is proposed, which consists in an integrated assessment of six elements (production, labor, financial, innovation, marketing and management) that have a direct impact on the competitiveness of the potential. A method of calculating the competitiveness of the potential of the business entity based on the method of ranking factors using expert assessments, which is based on a system of assessment indicators and takes into account the impact of each of the components. According to the presented approach, the competitive potential of an industrial enterprise is proposed to be defined as the sum of local potentials, taking into account the share of each of them in the overall structure of the total competitive potential. The practical application of this technique allows you to: analyze the current state and trends in the development of the business entity; identify the problems facing the company; develop management decisions aimed at increasing competitiveness; compare the competitive positions of enterprises with each other; to form conclusions about the available competitive potential of the production enterprise.

Keywords: competition, competitive potential, competitiveness assessment, integrated method, production enterprise.

Постановка проблеми. Глобальні зміни, що притаманні економічним процесам останніх років, детермінують формування сучасних підходів до розуміння такого складного явища, як конкурентний потенціал, що виступає основним фрактором підвищення загальної ефрективності діяльності підприємства. Особливої уваги заслуговує проблема підвищення конкурентоспроможності потенціалу виробничих підприємств, актуальна її оцінка із врахуванням впливу основних показників виробничої діяльності з метою забезпечення подальшого сталого розвитку підприємств в перманентно мінливому ринковому середовищі. В сучасних умовах господарювання дана проблема набуває все більшого практичного значення і від іï оперативного вирішення залежить подальша стратегічна стабільність вітчизняної промисловості. Важливість і актуальність даних питань привертають значну увагу наукового товариства, менеджменту підприємств реального сектора економіки своєю різнобічністю і багатоаспектністю невирішених теоретичних та практичних проблем.

Аналіз останніх досліджень і публікацій. Методологічні основи есрективного фуннціонування підприємств та підвищення ïх конкурентоспроможності із врахуванням значення окремих фракторів в процесі виробництва відображаються в працях вчених класичної економічної школи: П. Буагільбера, У. Петті, Д. Рікардо, А. Сміта, Ж. Сея та інших. Подальше становлення теорії ресурсів і фракторів виробництва дає змогу сформувати уявлення про виробничий потенціал підприємства. Значний вплив на розвиток даного напряму мали роботи неокласиків: Дж.Б. Кларка, А. Маршалла, В. Парето. Дослідженню методичних підходів до оцінки есрективності використання конкурентного потенціалу підприємств присвячені праці наступних закордонних авторів: І. Ансофрфа, М. Портера, Дж. Робінсона, П. Самуельсона, Дж. Траута, Г. Тяна, Ф. Хайека, П. Хейне, Е. Чемберліна. Серед українських вченихекономістів, які брали активну участь у дослідженнях оцінки конкурентоспроможності слід відзначити В. Диканя, Л. Закревську, О. Кузьміна, Д. Погребняка, С. Салигу, В. Сахна, А. Темченка, А. Ткаченко, А. Черепа.

Виділення невирішених раніше частин загальної проблеми. Незважаючи, на отримані значні наукові результати як в загальнотеоретичному, так і в прикладному аспекті, постає цілий ряд питань, пов'язаних з розробкою методичного підходу до оцінки конкурентоспроможності підприємства. Залишаються невивченими або дискусійними та зумовлюють необхідність проведення подальших досліджень питання вибору методики, яка б найбільш повно змогла охопити особливості оцінки конкурентного потенціалу суб'єктів господарювання.

Формулювання цілей статті (постановка завдання). Наукове обґрунтування теоретико-методологічної бази і методичного підходу до інтегральної оцінки конкурентного потенціалу виробничого підприємства, а також розробка на основі отриманих висновків практичних рекомендацій щодо досліджуваного напряму.

Виклад основного матеріалу дослідження. В сучасних умовах розвиток інорормаційного суспільства, пришвидшення інтеграційних процесів та подальше впровадження економіки знань, призвели до того, що підходи до забезпечення конкурентних переваг підприємства зазнали суттєвих трансорормацій. Так, такі традиційні конкурентні переваги (частка ринку, низькі витрати, якість обслуговування) вже не можуть в повній мірі забезпечувати безумовного лідерства підприємницьких струк- 
тур. В результаті еволюція економічних систем призвела до того, що в сучасних умовах конкурентні переваги проявляються у якості унікальних комбінацій ресурсів і ключових компетенцій, бачення перспектив розвитку, стратегічної гнучкості продуктів, технологій і послуг.

Очевидно, що забезпечення стратегічної конкурентоспроможності підприємства має ґрунтуватися на розуміння базових понять, основним серед яких $€$ конкурентоспроможність. Зважаючи на широкий спектр наукових досліджень даної проблеми, виокремимо лише їі базові положення. Так, основоположник теорії конкурентоспроможності М. Портер вважає, що остання відображає «властивість суб'єкта ринкових відносин виступати на ринку нарівні з присутніми там конкуруючими суб'єктами» [1, с. 480]. Дане визначення дає нам змогу констатувати, що по-перше ознакою конкурентоспроможності підприємства на ринку є його виробнича діяльність i, по-друге, обернене твердження, що здатність підприємства до конкуренції забезпечує його присутність та виживання на ринку.

Беззаперечним $€$ те, що конкурентоспроможність підприємства нерозривно пов'язана з системою його конкурентних переваг та $€$ наслідком їх реалізації. Це нова якісна характеристика підприємства, що забезпечує його підприємницький успіх на ринку, основу якого фрормує комплекс позитивних особливих відмінностей необхідних для протидії негативним впливам зовнішнього середовища 3 метою реалізації поставлених конкурентних цілей суб'єкта господарювання. Варто відзначити і той момент, що конкурентоспроможність - це не лише результат реалізації конкурентних переваг, а й наслідок значної кількості розрахунків щодо основних напрямів діяльності суб'єкта конкуренції. Все це зумовлює поглиблення дослідження конкурентоспроможності у різних іiї фрормах прояву, зокрема, і потенційній.

Обов'язковими умовами формування шляхів підвищення конкурентоспроможності підприємства $€$ оцінка та аналіз його реального стану, що ґрунтується на можливостях фрактичної ресурсної бази і перспективах розвитку. На даний час наукові дослідження у даному напрямі представлені значною кількістю різноманітних методик оцінки конкурентоспроможності виробничого потенціалу, в основу яких здебільшого покладене дослідження ефрективності використання конкретних видів ресурсів на підприємстві, або вимірювання підсумкових результатів виробничо-господарської діяльності.
Методи оцінки і діагностики рівня використання виробничого потенціалу промислових підприємств та їх конкурентоспроможності, що існують в даний час, ґрунтуються на деяких принципових підходах, які в більшості своїй використовують економіко-статистичні залежності. До даних методів належать кількісні, які дають можливість оцінити за допомогою математичного апарату конкурентні переваги потенціалу підприємства та прийняти відповідні управлінські рішення $[2$, с. $24 ; 3$, с. 113$]$. Вони забезпечують можливість цілісно вивчити і системно проаналізувати діяльність промислових підприємств, обґрунтувати залежність і взаємну обумовленість, а також кількісну характеристику зв'язку між результуючими показниками і фракторами виробництва.

Так, В.Г. Герасимчук пропонує оцінювати виробничий потенціал підприємства і його конкурентоспроможність за допомогою розрахункової та аналітичної інфрормації, що характеризує кваліфікаційний рівень кадрів, ступінь використання обладнання, фрінансові можливості, резерви [4]. Вважаємо, що запропонований підхід до оцінки конкурентоспроможності виробничого потенціалу носить дещо суб'єктивний характер і не може забезпечити порівнянність різних показників, що зумовлює труднощі при розрахунку і порівнянні з іншими конкурентами.

Існує значна кількість праць в яких класисріковано і подано основні групи методів оцінки конкурентоспроможності потенціалу підприємства. Тому, вважаємо за доцільне зосередити свою увагу не на класифікації даних методів, а на вироблені підходу до проведення оцінки. Слід лише відзначити, що доцільним, на нашу думку, $є$ підхід до групування даних методів запропонований Азоевим Г.Л. [4]. Відповідно до даного підходу всі методи об'єднані у дев'ять груп:

- методи, засновані на аналізі порівняльних переваг;

- методи, засновані на теорії якості товару;

- методи, що базуються на теорії рівноваги фрірми і галузі;

- матричні методи оцінки конкурентоспроможності;

- методи, побудовані на основі теорії ефективної конкуренції;

- метод визначення позиції в конкуренції 3 точки зору стратегічного потенціалу підприємства;

- методи засновані на порівнянні з еталоном;

- інтегральний метод;

- метод, заснований на теорії мультиплікатора. 
Зважаючи на мету нашої роботи, вважаємо, що значний інтерес при срормуванні методики оцінки конкурентоспроможності потенціалу промислових підприємств представляють методи, які можуть широко застосовуватись на практиці, а саме: експертні методи, рейтинговий порівняльний аналіз, імітаційне моделювання, фракторний аналіз, економіко-математичне моделювання, інтегральний метод. На нашу думку, перспективність застосування даних методів зумовлена постійними і значними змінами, що відбуваються в технологіях, які застосовуються для оцінки поточного стану та вироблення ефективних і результативних стратегій перспективного розвитку підприємства. Проте, на даний час відсутній цілісний, системний підхід до вимірювання виробничого потенціалу підприємства, який дав би змогу враховувати наявні потенційні можливості підприємства 3 метою забезпечення подальшого розвитку господарюючого суб'єкта і його конкуренто- спроможності. Все це зумовлює до пошуку і вибору дієвої методики оцінки конкурентоспроможності потенціалу виробничого підприємства.

Аналіз існуючих методичних підходів дає змогу звернути увагу на інтегральний метод, що дає змогу забезпечити комплексний підхід до оцінки конкурентоспроможності потенціалу підприємства та на практиці отримати оцінки конкурентних позицій підприємства за допомогою конкретних показників. Доцільність застосування пропонованого підходу полягає і в тому, що він в реальних умовах фуункціонування підприємства дає змогу в рівній мірі врахувати як конкурентоспроможність продукції, так і ефрективність виробничо-господарської діяльності підприємства.

3 метою розрахунку інтегрального показника конкурентоспроможності спочатку необхідно досліджувати вплив різноманітних чинників на конкурентоспроможність потенціалу

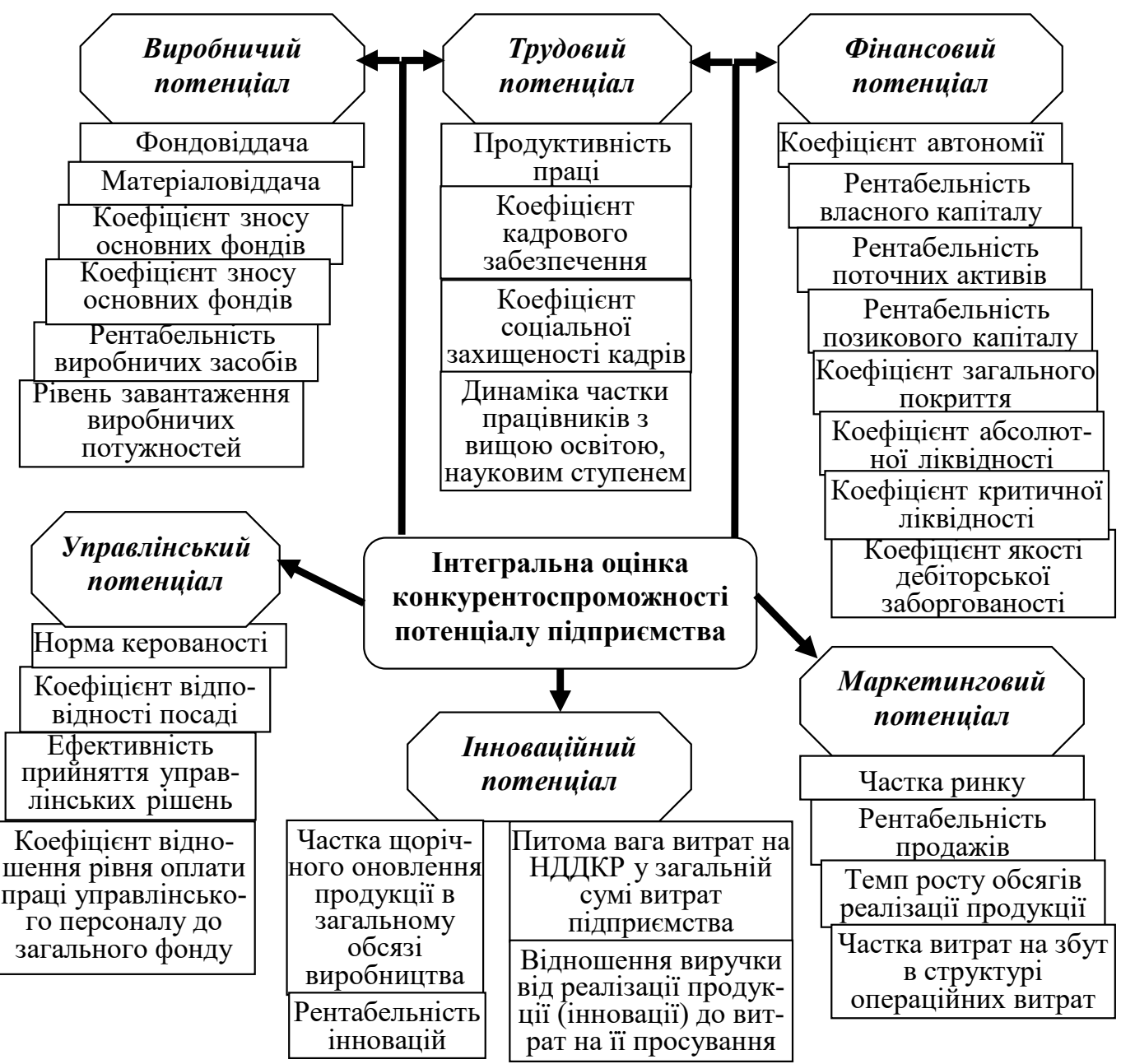

Рис. 1. Методичний підхід до оцінки конкурентного потенціалу виробничого підприємства 
суб'єкта господарювання. Розгляд таких чинників наводився в багатьох наукових працях, серед яких, вважаємо, варто відзначити наступні [6, с. 80; 7, с. 36; 8].

Аналіз наукових праць 3 даної проблеми дав нам змогу запропонувати методичний підхід до оцінки конкурентоспроможності потенціалу підприємства, який полягає в тому, що для отримання інтегральної оцінки необхідний ретельний аналіз шести елементів (виробничий, трудовий, срінансовий, інноваційний, маркетинговий і управлінський), що чинять безпосередній вплив на конкурентоспроможність потенціалу, з формуванням по кожному із них системи показників оцінки (рис. 1).

Запропонована нами інтегральна оцінка конкурентного потенціалу виробничого підприємства базується на методиці розрахунку конкурентоспроможності господарюючого суб'єкта на основі методу ранжирування фракторів за допомогою експертних оцінок.

Практичне застосування представленого підходу вимагає ретельного підбору авторитетних і компетентних експертів та обчислення коефріцієнта конкордації для визначення ступеня узгодженості думок [9, с. 379], що зумовлює деякі складності щодо його реалізації. Проте, перевагами використання саме методу експертних оцінок $€$ те, що він дозволяє отримати комплексну оцінку на основі оцінок різних за змістом елементів конкурентного потенціалу, які звести до спільних одиниць виміру немає змоги. Як вже зазначалось вище, на основі літературного аналізу і вивчення облікової практики в рамках кожного елемента конкурентного потенціалу були виділені основні показники, що характеризують ресурси, компетенції та можливості 3 урахуванням особливостей фрункціонування підприємств.

Відповідно до представленого підходу конкурентний потенціал промислового підприємства пропонується визначати як суму локальних потенціалів, із врахуванням питомої ваги кожного з них у загальній структурі сукупного конкурентного потенціалу:

$$
I_{\text {КПп }}=\sum_{j=1}^{n} \alpha_{\kappa \Pi j} \times K \Pi j=\sum_{i=1}^{n} \alpha_{K \Pi j} \times\left(\sum_{i=1}^{m} \beta \Pi_{i j} \times \Pi_{i j}\right)
$$

де $I_{\text {кпп }}$ - інтегральна оцінка конкурентного потенціалу промислового підприємства;

$\kappa П j$ - оцінка j-го локального потенціалу в структурі конкурентного потенціалу підприємства;

$\alpha K П j$ - питома вага $j$-го локального конкурентного потенціалу промислового підприємства; $n$ - кількість локальних потенціалів в складі конкурентного потенціалу;

$\Pi_{i j}$ - оцінка часткового $і$-го показника в структурі $j$-го локального конкурентного потенціалу промислового підприємства;

$\beta \Pi_{i j}$ - вага часткового $i$-го показника в структурі $j$-го локального конкурентного потенціалу промислового підприємства;

$m$ - кількість часткових показників в складі j-го локального потенціалу конкурентного потенціалу підприємства.

Інтегральний показник оцінки конкурентного потенціалу промислового підприємства, розрахований методом ранжирування фракторів на основі експертних оцінок, дає змогу проаналізувати наявні резерви і можливості розвитку господарюючого суб'єкта та розробити заходи щодо подальшого підвищення конкурентоспроможності його фрункціонування.

Висновки. Аналіз існуючих підходів до оцінки конкурентного потенціалу промислового підприємства дав змогу виявити ряд недоліків, до яких, в першу чергу слід віднести складність щодо порівнянності оцінок окремих складових потенціалу з позиції одночасної наявності при оцінці кількісних і якісних показників. Запропонований методичний підхід інтегральної оцінки конкурентного потенціалу виробничого підприємства забезпечує можливість у значній мірі нівелювати даний недолік.

Сорормований підхід забезпечує комплексну інтегральну оцінку по шести складових конкурентного потенціалу виробничого підприємства, що безпосередньо впливають на конкурентоспроможність: виробничого, трудового, фрінансового, інноваційного, маркетингового і управлінського. Аналіз здійснюється за окремими показниками, що характеризують кожен із шести елементів конкурентного потенціалу підприємства, після чого формується інтегральний бальний показник оцінки конкурентоспроможності на основі експертних оцінок.

Практичне застосування даної методики дозволяє: проаналізувати поточний стан і тенденцій у розвитку суб'єкта підприємництва; визначити проблеми, що постали перед підприємством; розробити управлінські рішення спрямовані на підвищення конкурентоспроможності; порівняти конкурентні позиції підприємств між собою; сорормувати висновки про наявний конкурентний потенціал виробничого підприємства. 


\section{СПИСОК ВИКОРИСТАНИХ ДЖЕРЕЛ:}

1. Портер М. Конкуренция. Москва : Вильямс, 2000.

2. Ільницька-Гикавчук Г.Я. Методи оцінки конкурентоспроможності туристичних підприємств. Вісник Хмельницького національного університету. Економічні науки. 2018. № 3(1). С. 24-27.

3. Кваско А.В. Аналіз методів оцінки конкурентоспроможності підприємства. Наукові записки. 2017. № 1(54). C. 111-118.

4. Герасимчук В.Г. Диагностика систем управления предприятием : Научное пособие. Москва : ИСдО, 1995.

5. Азоев Г.Л. Конкуренция: анализ, стратегия, практика. Москва : Центр экономики и маркетинга, 1996.

6. Амосов О.Ю. Оцінка потенціалу конкурентоспроможності як основного аспекту розвитку підприємства. Проблеми економіки. 2011. № 3. С. 79-83.

7. Халімон Т.М. Формування та оцінка потенціалу конкурентоспроможності підприємства. Економічний вісник Запорізької державної інженерної академії. 2016. № 5(2). С. 35-39.

8. Кузьмін О.Є., Мельник О.Г., Романко О.П. Конкурентоспроможність підприємства: планування та діагностика : монографія. Івано-Франківськ : ІФНТУНГ, 2011.

9. Трасковецька Л.М., Боровик Л.В., Боровик, О.В. Автоматизація математичних методів експертних оцінок. Збірник наукових праць Національної академії Державної прикордонної служби України. Сер. : Військові та технічні науки. 2013. № 2. С. 373-384.

\section{REFERENCES:}

1. Porter, M. (2000). Konkurentsyya [Competition]. Moscow: Williams. (in Russian)

2. Ilnytska-Hykavchuk, G.Ya. (2018). Metody otsinky konkurentospromozhnosti turystychnykh pidpryyemstv [Methods for assessing the competitiveness of tourism enterprises]. Visnyk Khmel'nyts'koho natsional'noho universytetu - Ekonomichni nauky Bulletin of Khmelnytsky National University. Economic Sciences, 3(1), 24-27. (in Ukrainian)

3. Kvasko, A.W. (2017). Analiz metodiv otsinky konkurentospromozhnosti pidpryyemstva [Analysis of methods for assessing the competitiveness of the enterprise]. Naukovi zapysky - Scientific Notes, 1(54), 111-118. (in Ukrainian)

4. Gerasimchuk, V.H. (1995). Dyahnostyka system upravlenyya predpryyatyem: Nauchnoe posobye [Diagnostics of enterprise management systems: Scientific manual]. Moscow: ISDO. (in Russian)

5. Azoev, H.L. (1996). Konkurentsyya: analyz, stratehyya, praktyka [Competition: analysis, strategy, practice]. Moscow: Center for Economics and Marketing. (in Russian)

6. Amosov, O.Yu. (2011). Otsinka potentsialu konkurentospromozhnosti yak osnovnoho aspektu rozvytku pidpryyemstva [Assessment of the potential of competitiveness as a key aspect of enterprise development]. Problemy ekonomiky - Problems of Economics, 3, 79-83. (in Ukrainian)

7. Khalimon, T.M. (2016). Formuvannya ta otsinka potentsialu konkurentospromozhnosti pidpryyemstva [Formation and assessment of the competitiveness potential of the enterprise]. Ekonomichnyy visnyk Zaporiz'koyi derzhavnoyi inzhenernoyi akademiyi - Economic Bulletin of the Zaporizhia State Engineering Academy, 5(2), 35-39. (in Ukrainian)

8. Kuz'min, O.Ye., Mel'nyk, O.H., \& Romanko, O.P. (2011). Konkurentospromozhnist' pidpryyemstva: planuvannya ta diahnostykaKonkurentospromozhnist' pidpryyemstva: planuvannya ta diahnostyka [Competitiveness of the enterprise: planning and diagnostics]. Ivano-Frankivsk: IFNTUNG. (in Ukrainian)

9. Traskovets'ka, L.M., Borovyk, L.V., \& Borovyk, O.V. (2013). Avtomatyzatsiya matematychnykh metodiv ekspertnykh otsinok [Automation of mathematical methods of expert evaluations]. Zbirnyk naukovykh prats' Natsional'noyi akademiyi Derzhavnoyi prykordonnoyi sluzhby Ukrayiny. Ser.: Viys'kovi ta tekhnichni nauky - Collection of scientific works of the National Academy of the State Border Guard Service of Ukraine. Ser.: Military and Technical Sciences, 2, 373-384. (in Ukrainian) 